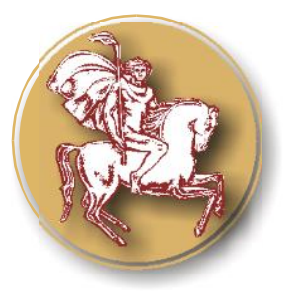

Original Contribution

\title{
GROWTH AND DEVELOPMENT OF LEGUME AND GRASS COMPONENTS IN MIXED GRASSLANDS GROWN IN THE CENTRAL BALKAN MOUNTAIN
}

\author{
T. Bozhanska*, B. Churkova \\ Research Institute of Mountain Stockbreeding and Agriculture, Troyan, Bulgaria
}

\begin{abstract}
PURPOSE of the present study is to establish the growth, development and competitiveness of grass and legume components in mixed grasslands grown under the conditions of the Central Balkan Mountains.

METHODS: In the spring of 2014-2016, the growth and development of typical meadow legumes and grass species for that region were observed in the experimental field of RIMSA - Troyan, in double mixtures: 1. Bird's-foot-trefoil - Red fescue; 2. White clover - Perennial ryegrass; 3. White clover - Kentucky bluegrass; 4. Red clover - Timothy-grass; 5. Blue hybrid alfalfa - Cock's foot; 6. Red clover - Meadow fescue.

RESULTS: From all grass crops - Dactylis glomerata L. has the most pronounced competitive ability with respect to the biometric height indicator of plants, while Poa pratensis L. has the slightest one. For the three-year study period, Trifolium repens L. in its mixture with Lolium perenne L. recorded the lowest average growth values compared to the other legumes included in the experiment.

CONCLUSIONS: The best intercompatibility and, respectively, the most favorable combination of grass and legume components is found between Trifolium pratense L. and Festuca pratensis L., and the weakest among the components in the blue hybrid alfalfa - cock's foot mixture.

The length of the flower-bearing stems and leaf stalks of Trifolium pratense L. in the mixed grassland with meadow fescue have higher values $(41.8: 89.0 \mathrm{~cm})$ and those with timothy-grass are lower $(38.1: 52.5 \mathrm{~cm})$.
\end{abstract}

Key words: grass mixtures, heights, variation coefficient, growth and development

\section{INTRODUCTION}

Ecological researches (1) show significant changes in the Earth's climate, which requires extensive studies on the adaptability of plant species to the cultivation conditions $(2,3)$.

The optimal combination of certain types of grass and legume species could provide advantages for mixed grasslands for the better use of environmental resources $(4,5)$, growth and development of plants.

The ecological conditions and the usage regime regulate the interaction of the grass and legume component in the mixture and

*Correspondence to: Tatyana Bozhanska, 281

Vasil Levski Street, 5600-Troyan, Bulgaria,

E-mail: tbozhanska@mail.bg determine its organic production (6-9) and the quality of the grass mass $(10,11)$.

In this sense, the white clover has good compatibility both with Kentucky bluegrass and perennial ryegrass, but the variants with the legume grass of Poa pratensis L. (12) has better realization of clover plants and higher productivity. This necessitates a suitable selection of the types of grasses and legumes to maintain the dynamic stability in mixed grasslands.

The purpose of the present study is to establish the growth, development and competitiveness of grass and legume components in mixed grasslands grown under the conditions of the Central Balkan Mountains. 


\section{MATERIAL AND METHODS}

The experiment was set in the spring of 2014 at the Research Institute of Mountain Stockbreeding and Agriculture - Troyan, using the block method in four replications with the size of the $5 \mathrm{~m}^{2}$ plot. The study period is three years. Experimental variants are: 1. Bird'sfoot-trefoil (Lotus corniculatus L.) + Red fescue (Festuca rubra L.); 2. White clover (Trifolium repens L.) + Perennial ryegrass (Lolium perenne L.) 3. White clover (Trifolium repens L.) + Kentucky bluegrass (Poa pratensis L.) 4. Red clover (Trifolium pratense L.) + Timothy-grass (Phleum pratense L.); 5. Blue hybrid alfalfa (Medicago sativa L.) + Cock's foot (Dactylis glomerata L.); 6. Red clover (Trifolium pratense L.) + Meadow fescue (Festuca pratensis L.).

Soil preparation includes autumn plowing of self-sown fallow ground at a depth of 22-25 $\mathrm{cm}$ and repeatedly spring disc, milling and rolling before and after sowing.

The sowing of the field experiment was carried out manually, scattered, at the optimum agrotechnical period (the middle of March) on a pre-created solid bed at a depth of 0.5-1.0 $\mathrm{cm}$. Sowing rates were calculated on the basis of $100 \%$ seed germination as for bird's-foottrefoil and white clover is $1.2 \mathrm{~kg} / \mathrm{da}$, for red clover $-1.5 \mathrm{~kg} / \mathrm{da}$, and for blue hybrid alfalfa $2.5 \mathrm{~kg} / \mathrm{da}$. Grasses in the grass mixtures are sown with a $2.5 \mathrm{~kg} / \mathrm{da}$ sowing rate. The ratio of components in the mixtures is 50:50. Immediately after sowing, sown areas are rolled for better seed contact and soil germination.

Seeds of the most common cultivars of legumes and meadow grasses were used: Bird's-foot-trefoil - 'Leo', White clover - Huia, Red clover - 'Altaswede', Blue hybrid alfalfa, a local population of Troyan origin and Red fescue - 'Ryder', Meadow fescue - 'Laura', Cock's foot - 'Loke', Kentucky bluegrass 'Sobra', Timothy-grass - 'Erecta' and Perennial ryegrass - 'Belida'.

Fighting weeds during vegetation is mechanical in order to avoid further chemical interference with plants. The grasslands were
BOZHANSKA T., et al. cut in the beginning of the blossoming phase of the legumes and tasseling/ear formation of grass crops.

The height of mowing $(\mathrm{cm})$ of the grassland is observed at the time of harvesting. The plants (at 4 points) are measured from the surface of the soil to the top of the highest stems in both diagonals of each parcel. The height is reported by components (of each variant of 40 plants of a species) by year and regrowth. The average indicators are calculated on the basis of data obtained.

The degree of variation (CV) of parameters was determined through variation coefficient according to the scheme of Mamaev: up to $7 \%$ - very low; 7.1 to $12.0 \%$ - low; 12.1 to $20.0 \%$ - moderate; 20.1 - $40.0 \%$ - high; over $40.0 \%$ very high.

\section{RESULTS AND DISCUSSION \\ Height of plant stems in grass-legume mixtures.}

The height of the components in the grassland provides information related to the combined use of grasses and legumes, assesses their compatibility, which in turn influences the stability and productivity of the mixed crop in the predominantly unfavorable soil and climatic conditions in the mountainous regions (Figures 1, 2 and 3).

For the three-year study period, the white clover in its mixture with perennial ryegrass (variant 2) recorded the lowest average growth rates compared to the remaining legumes included in the experiment. The data show minimal differences in heights of this leguminous crop during spring and summer regrowth. The type of grass component affected the height of flower-bearing stems and leaf stalks of white clover. They are with 8.2 to $8.6 \mathrm{~cm}$ taller in association with Kentucky bluegrass than those in the mixture with perennial ryegrass.

In the year of establishment of the mixed grasslands, alfalfa shows the highest average height among legumes, in the second vegetation - red clover (in the variant with meadow fescue) and in the third - bird's-foottrefoil. 
BOZHANSKA T., et al

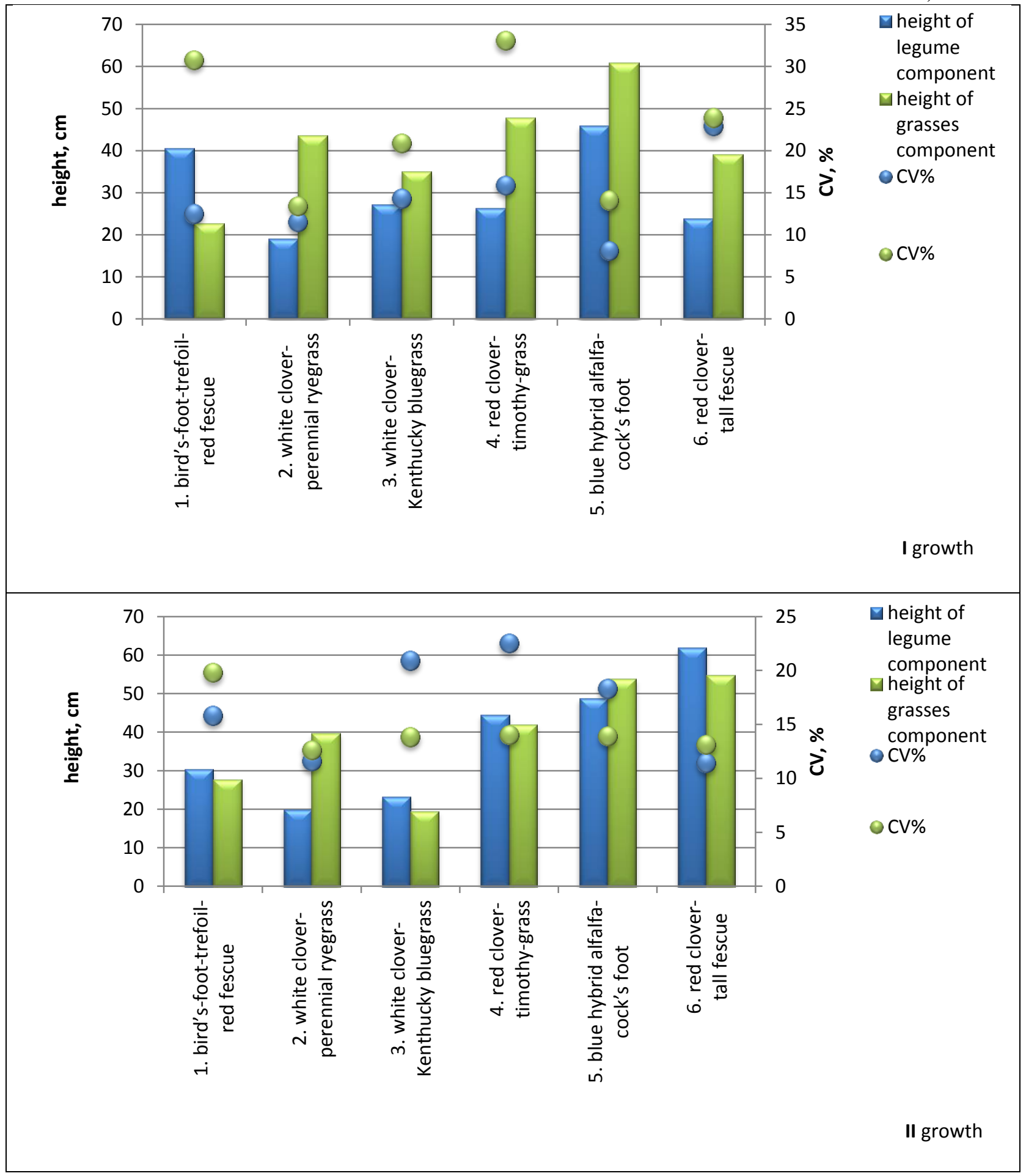

Figure 1. Height of grass and legume components in mixed grasslands in first vegetation, by regrowth $(\mathrm{cm})$

In the second one in 2015, red clover plants in its mixture with meadow fescue are higher in the spring regrowth $(46.5 \mathrm{~cm})$ compared to the summer $(42.2 \mathrm{~cm})$, when the conditions of the environment favour its development.

In the third vegetation of Lotus corniculatus L., we observe a reverse trend. Plants in the first regrowth are about $20 \mathrm{~cm}$ lower than the second one $(63.2 \mathrm{~cm})$, which confirms the great ecological plasticity and draught resistance of this crop.

In the sowing year the variation of this indicator in the blue alfalfa crops is low (CV: $8.1 \%$ ) to a medium high (CV: $18.3 \%$ ) respectively in the first and second regrowth, while in the second vegetation the height of the stems of red clover have a high coefficient of variation (CV: $26.3 \%$ - spring and CV: $23.9 \%$ summer regrowth). In 2016, the values of 
variation in the height of bird's-foot-trefoil in the regrowths were average (CV: $15.7 \%)$ in spring and high in summer regrowth $(\mathrm{CV}$ : $25.7 \%)$.

The type of grass component affected the growth of red clover. In the mixture with timothy-grass, the plants remained lower, both in the spring and summer regrowths compared to those in the mixture with meadow fescue. This gives reason to believe that the competitive ability of timothy grass exceeds that of the meadow fescue.

In the year of sowing, the red fescue has the lowest values for the stem height in spring $(22.7 \mathrm{~cm})$ and Kentucky bluegrass in the summer regrowth $(19.5 \mathrm{~cm})$. Such occurrence of Kentucky bluegrass is observed in the second and third vegetation, with no significant difference in the height of stems during the wet spring and dry summers. In the first regrowth of the third vegetation, Kentucky bluegrass, in the mixture with white clover, has the same height as perennial ryegrass $(48 \mathrm{~cm})$, associated with the same legume grass. In the summer regrowth, perennial ryegrass stems retain the values of the indicator while Kentucky bluegrass is significantly higher (approximately $10 \mathrm{~cm}$ ). In the first vegetation, bird's-foot-trefoil and red clover are superior in height to the grass components with which they are combined in the mixtures. In the second and third vegetation, the legumes remain lower than the grass species. Meadow fescue and cock's foot (with the exception of fescue in the first regrowth of 2014) have the highest stems in the regrowths by year and average for the experimental period.

In the first experimental year in the spring regrowth of bird's-foot-trefoil - red fescue mixture, the leguminous component has higher values for the stem height $(40.6 \mathrm{~cm})$ compared to grass component $(22.7 \mathrm{~cm})$ - the regularity associated with the biological features of both crops (Figure 1).

The summer regrowth of the mixture have a better uniformity in plant height due to one of the advantages of grasses compared to legumes, namely their higher competitive and adaptive capacity.

In a second regrowth, the plants of Lotus L. are $10.2 \mathrm{~cm}$ lower than the first one, and those of the genus Festuca L. with $5 \mathrm{~cm}$ higher. For the same period, the coefficient of variation of the
BOZHANSKA T., et al. grass and legume component was CV: $28.3 \%$ and $12.6 \%$, respectively. In 2015 (Figure 2), the growth rate of Lotus corniculatus L. and Festuca rubra L. retained the trend of the first vegetation. Red fescue forms almost twice as high grassland in the first $(61.7 \mathrm{~cm})$ and second $(67.6 \mathrm{~cm})$ regrowth compared to the bird's-foot-trefoil. This is due to the fact that the species in the studied grasslands fall into a cenotic group, which corresponds to their relatively weak aggressiveness and good intercompatibility in the grass mixture (13).

In the third year of the experiment, the mixture of bird's-foot-trefoil - red fescue is one of the most balanced and close share participation of grass and legume component in grass biomass.

The average height of bird's-foot-trefoil in the spring and summer regrowth is 42.8 and 63.2 $\mathrm{cm}$ respectively, while fescue is 66.6 and 71.3 $\mathrm{cm}$ respectively. From the analyzed data we find that in 2016 Festuca rubra L. recorded about $6.6 \mathrm{~cm}$ higher grassland compared to the average height of the plants $(50-60 \mathrm{~cm})$ established for this crop.

In the year of sowing, there is no significant difference in the height of the plants in both regrowth in the mixture of white clover perennial ryegrass. Values of clover in its mixtures with perennial ryegrass are lower compared to its mixtures with Kentucky bluegrass. There are aspects of both intraspecies and inter-species competition in the mixed cultivation of two or more species (14). As an explanation for what is observed in this experiment, it can be mentioned the rapid growth rate and the great competitive ability of ryegrass, which lead to suppression of the development of the basic legume species in the mixture, which grows more slowly in the year of its sowing. The results obtained for the second and third vegetation from the life cycle of the grassland are similar. The average height of clover and perennial grassland in 2015 and 2016 has minimal difference in spring and summer regrowth $(0.3$ to $1.5 \mathrm{~cm})$. The data from the analysis show a higher degree of variation in the grassland of the leguminous crop for the second vegetation (CV: 23.2$27.3 \%$ ), compared to the third one (CV: 11.0$19.2 \%)$. They are opposed to the results of the coefficient of variation (CV: $15.4-14.6 \%$ for 2015 and CV: $30.8-22.7 \%$ for 2016) for grass crop respectively in spring and summer regrowth. 
BOZHANSKA T., et al

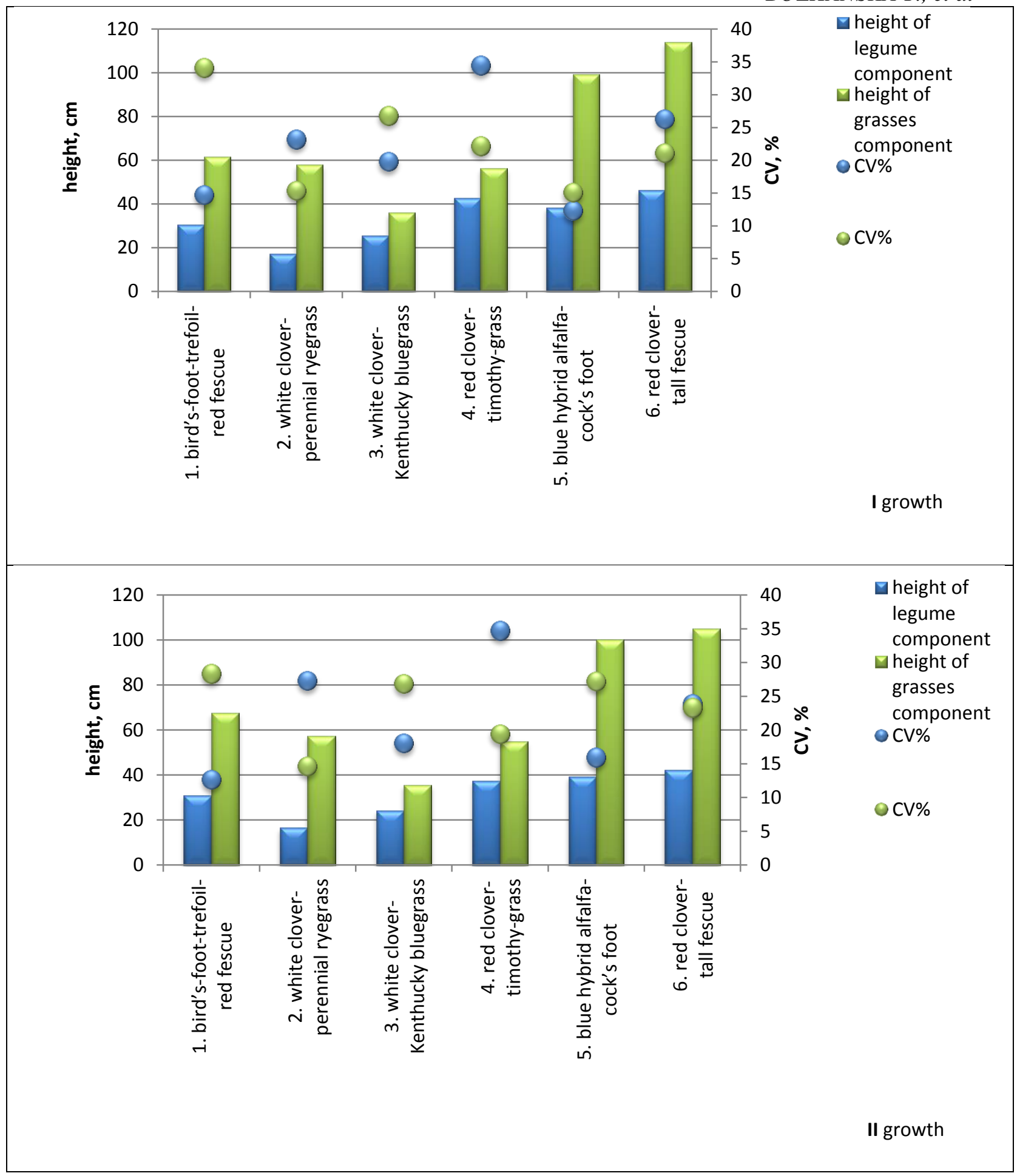

Figure 2. Height of grass and legume components in mixed grasslands in second vegetation, by regrowths $(\mathrm{cm})$

White clover shows greater competitive ability than grass crop, when it is Associated with Kentucky bluegrass. Its height in the spring regrowths in the first, second and third experimental years (Figures 1, 2 and 3) reaches 27.2, 25.7 and $23.3 \mathrm{~cm}$ (compared to those of the Kentucky bluegrass - 35.0, 36.0 and $48 \mathrm{~cm}$ ), and in the summer regrowths23.2, 24.2 and $22.2 \mathrm{~cm}$ (compared to those of Kentucky bluegrass - 19.5, 35.6 and $59.0 \mathrm{~cm}$ ).
In the first (2015 and 2016) and second (2014 and 2015) regrowth, the grass component recorded the lowest values in the plant height indicator compared to other perennial grass components. Kentucky bluegrass has a high coefficient of variation $(\mathrm{CV}>20 \%)$ in the year of sowing and in the summer regrowth of the second vegetation. The variation indicator of white clover average for the period of 20142016 is $\mathrm{CV} \leq 20 \%$. 
BOZHANSKA T., et al.

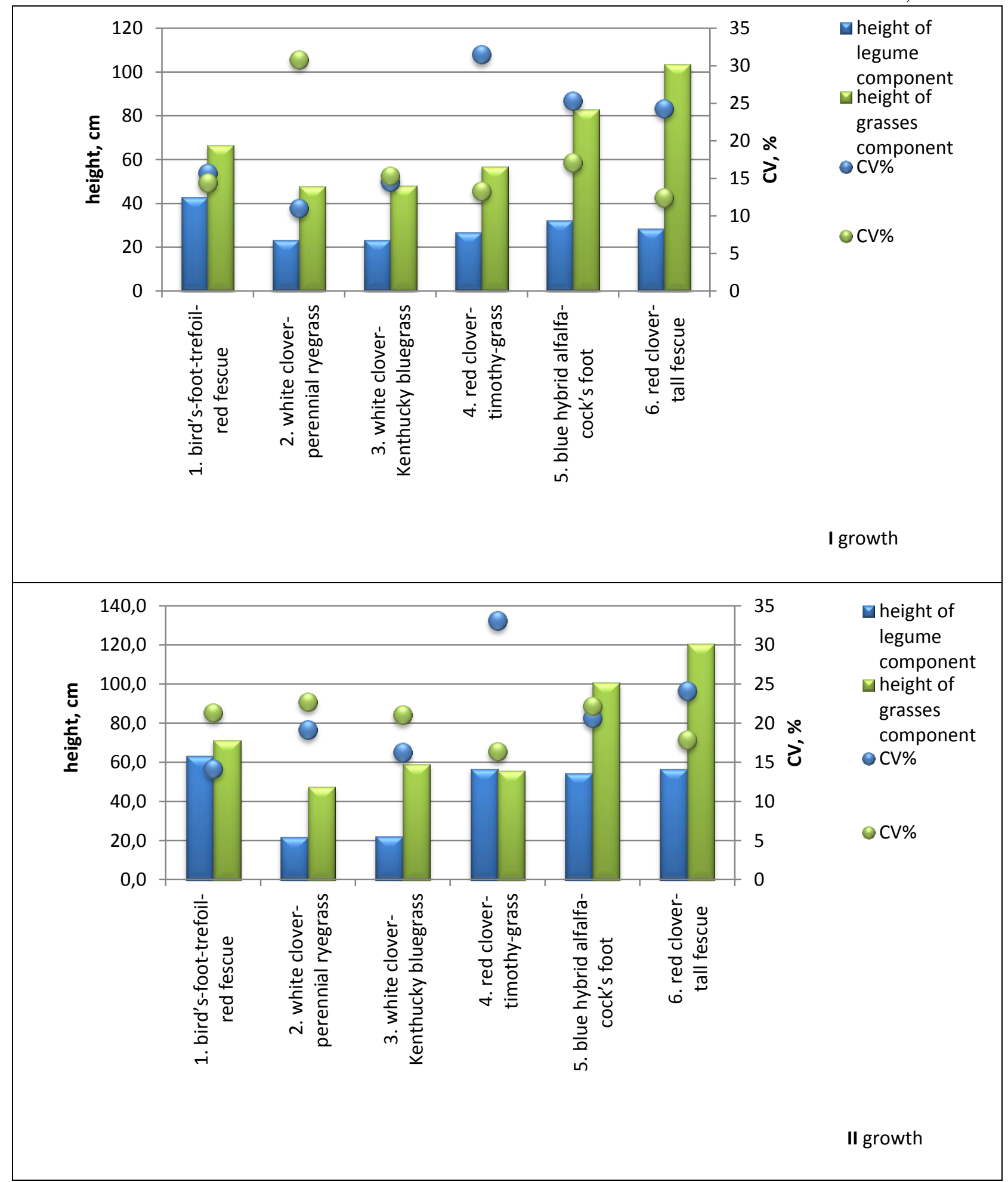

Figure 3. The height of grass and legume components in mixed grassland in third vegetation, by regrowths $(\mathrm{cm})$

The results of the analysis are related to the biological features of Kentucky bluegrass, which is a typical grazing grass and as it slows down its growth after mowing. Data determine its growth rate as the weakest for the three-year experimental period compared to other grasses. There are no significant differences in this mixture in the standard deviation in the height indicator of white clover in the spring and summer regrowths.

On average for the experimental period, the grassland of two-component mixture of Trifolium repens L. - Poa pratensis L. is less pronounced in the height of legume and grass crops $(24.3: 38.9 \mathrm{~cm})$, compared to the variant 
of Trifolium repens L. - Lolium perenne L. $(19.6: 49.0 \mathrm{~cm})$.

Good moisture availability during the first year of the experiment helped the growth rate of the plant species in the mixture of red clover timothy-grass. As a representative of a second cenotic group, red clover demonstrates a higher competitive ability and its height in the grassland of the first vegetation increased almost twice from the spring $(26.4 \mathrm{~cm})$ in the summer regrowth $(44.5 \mathrm{~cm})$, whereas in the grass crop the average plant height has a decreasing trend from the first $(47.9 \mathrm{~cm})$ in the second $(42.0 \mathrm{~cm})$ regrowth (Figure 1). The high temperatures and the lower soil and air humidity, along with the biologically inferior summer regrowth ability, determine the lower grassland of the meadow timothy-grass in the summer regrowths during the three-year experiment. In the second vegetation, in the warmer and drier year, the components in the mixture of red clover - timothy-grass shows a slightly higher grasslands in spring regrowth (42.8 - leguminous and $56.4 \mathrm{~cm}$ - grass crop) compared to summer (37.5 - legume and 55.0 $\mathrm{cm}$ - grass crop). In the third vegetation both components are equal in height, the ratio of both crops by this feature is $56.5: 55.7 \mathrm{~cm}$ in favour of meadow timothy-grass.

The biological characteristics of the individual species, as well as the interrelationships among them in mixed crops, influence their durability and purpose.

In 2014 in the initial stage of development of the mixture of red clover - meadow fescue, we observe a relatively low level of weed infestation. In the same period, legumes and grasses have significant differences in the height of the plants, cut in spring $(23.9 \mathrm{~cm}$ bean and $39.1 \mathrm{~cm}$ - grass) and summer (61.9 $\mathrm{cm}$ - beans and $54.9 \mathrm{~cm}$ - grasses) regrowth (Figure 1). This trend is not sustained in 2015, the second year of the experiment. The average height of Trifolium pratense L. and Festuca pratensis Huds. is greater in the spring (about $4 \mathrm{~cm}$ more for the legumes and $9 \mathrm{~cm}$ more for the grasses) compared to the summer regrowth. The environmental conditions favored the rapid growth of the meadow fescue and its plants reached the maximum of $114.1 \mathrm{~cm}$ - an indicator which is directly dependent on the productivity of this grass species grown in mixed grasslands. In the second regrowth of the second experimental year, the height ratio
BOZHANSKA T., et al of the grass components in the composition of the mixture of red clover - meadow fescue is 42.2:105.0 cm, with a high coefficient of variation $(\mathrm{CV}>20 \%)$ for both grasses.

There is a noticeable increase in the values of the standard deviation in the regrowths from the first to the second vegetation, both for legumes and grass crops. In 2016, the clover marked a significant difference in the average height of the plants in spring and summer regrowth (28.6 and $56.6 \mathrm{~cm}$ ) - Figure 3. The opposite is observed for the meadow fescue the height of the plants in the second regrowth $(120.5 \mathrm{~cm})$ is greater than the first one $(103.5$ $\mathrm{cm})$.

For 2014-2016, the average height of red clover has higher values in the mixed grassland with meadow fescue $(41.8: 89.0 \mathrm{~cm})$ and lower in the mixture with timothy-grass (38.1:52.5 $\mathrm{cm})$. The difference in standard deviation of clover in variant $4(\mathrm{SD}-9.8 \mathrm{~cm})$ and 6 (SD-8.2 $\mathrm{cm}$ ) is insignificant. The height of the stems of timothy-grass is characterized by a higher coefficient of variation of that characteristics compared to that of the meadow fescue.

Both crops in the composition of the mixture of blue hybrid alfalfa - cock's foot are representatives of the first cenotic group (15). Their aggressiveness and high competitive ability is a major factor in suppressing the development of weed vegetation. Grass crop is the predominant component according to the height characteristics of the grassland for the whole experimental period.

Data from the analysis indicate that Dactylis glomerata L. have higher values of growth in both regrowths in the year of sowing. The spring regrowths of cock's foot have better uniformity compared to the summer in the first and second vegetation and with a minimum difference in the values of the indicator (45.9 $\mathrm{cm}$ - spring and $48.7 \mathrm{~cm}$ - summer regrowth for 2014; $99.4 \mathrm{~cm} \mathrm{-} \mathrm{spring} \mathrm{and} \mathrm{100,1} \mathrm{cm} \mathrm{-}$ summer regrowth for 2015) - Figures 1 and 2. The ability of this culture to develop evenly throughout the year determines the high and well distributed productivity in summer (16, 17, 18). The summer regrowths of blue hybrid alfalfa in the first, second and third experimental years have higher plant stems than the spring. The data show a decreasing intercompatibility (from first to third vegetation) between legume and grass component in the mixture. This is confirmed 
by the exceptionally small percentage of alfalfa (about $2 \%$ in the grassland in the second vegetation and $2.5 \%$ in plant biomass of third one) and suggests lower quality of the harvested biomass $(12,19)$. The low relative soil and air humidity during the vegetation period in 2016 as well as the acidic soil reaction do not create good conditions for tuber bacteria, depress nitrogen fixation and do not positively affect the growth of blue hybrid alfalfa. This is the reason for the weaker growth of alfalfa grassland $(\mathrm{X}-32.2 \mathrm{~cm})$ and the high degree of variation in the spring and summer regrowth (CV: 25.3-22.2\%), compared to the legumes in the other variants. Cock's foot also recorded lower values relative to plant height $(82.8 \mathrm{~cm})$ than those found for this species - 100-140 cm. This crop prefers deep clay soils with sufficient content of lime that are absent in the growing area. The standard deviation in the height of the grassland of cock's foot in third vegetation is over $12 \mathrm{~cm}$, and the variation coefficient from 17.1 to $22.2 \%$ in the first and second regrowth.

\section{CONCLUSIONS}

During the experiment the soil and climatic characteristics of the area influenced the participation of the species in the mixed grasslands.

As for the grass components, cock's foot has the highest competitiveness with respect to the biometric height indicator of the plants, while Kentucky bluegrass is the weakest. Meadow fescue and cock's foot (with an exception of fescue in the first regrowth in 2014) have the highest stems in the regrowths by year and average for the experimental period.

On the basis of this indicator, the most favourable combination of grass and legume component is found in the mixture of red clover and meadow fescue. The mixture of blue hybrid alfalfa - cock's foot has the weakest adaptability and intercompatibility (from first to third vegetation) of the components. The share of alfalfa in the harvested biomass is significantly reduced (around 2.0\% in 2015 and 2.5\% in 2016).

For the three-year study period, white clover in its mixture with perennial ryegrass recorded the lowest average growth rates relative to the remaining legumes included in the experiment. The grassland of the two-component mixture of Trifolium repens L. - Poa pratensis L. has a lesser difference in the height of the legume
BOZHANSKA T., et al. and grass crop (24.3:38.9 cm), compared to the variant with Trifolium repens L. - Lolium perenne L. (19.6:49.0 cm).

The plants of Trifolium pratense L. have higher values for the length of flower-bearing stems and leaf stalks in the mixed grassland with meadow fescue $(41.8: 89.0 \mathrm{~cm})$ and lower in the variant with timothy-grass (38.1:52.5 $\mathrm{cm})$. The difference in the standard deviation of clover in both variants is insignificant.

\section{REFERENCES}

1. Fischer, G., Shah, M., van Velthuizen, H. and Nachtergaele, F.O., Global agroecological assessment for agriculture in the 21st Century. IIASA Research Report 0202, International Institute for Applied Systems Analysis, Laxenburg, Austria, p.119, 2001.

2. Reheul, D., De Cauwer, B., Cougon, M. and Aper J., What global and/or European agriculture will need from grasslands and grassland breeding over the next 10-15 zears for a sustainable agriculture. Eucarpia meeting in Dublin, 21.09.2011.

3. Vasileva, V. and Ilieva, A., Changes of some parameters in mixtures with birdsfoot trefoil. Proceedings of National Scientific Conference with International Participation Ecology and Health, 09 and 10 June 2016, Plovdiv, 251-258, 2016.

4. Turkington, R. A., Cavers, P. B. and Aarssen, L. W., Neighbour relationships in grass-legume communities: Interspecific contacts in four communities near London, Ontario. Canadian Journal of Botany, 55:2701-2711, 1977.

5. Sanderson, M. A., Goslee, S. C., Soder, K. J., Skinner, R. H., Tracy, B. F.and Deak, A., Plant species diversity, ecosystem function, and pasture management: A perspective. Can. J. Plant Sci., 87:479-487, 2007.

6. Churkova, B., Seed yield of birdsfoot trefoil grown in mixture with meadow grasses. Bulgarian Journal of Agricultural Science, 13:515-520, 2007.

7. Mitev, D. and Naydenova, G., Persistency of artificial swards with participation of Red fescue on the slopes of the Central Balkan mountains. V State of mixed swards of red fescue and birdsfoot trefoil. Journal of Mountain Agriculture on the Balkans, 11, 7:1342-1352, 2008.

8. Chourkova, B., Study of introduced meadow grasses in mixtures with birdsfoot 
trefoil under the agro-ecological conditions of Troyan. Biotechnology in Animal Husbandry, 26:429-434, 2010.

9. Mitev, D. and Naydenova, G., Durability of artificial sward with the participation of red fescue situated along the slopes of the Central Balkan mountain vi state of mixed sward of red fescue, kentucky bluegrass and birdsfoot trefoil. Banat's Journal of Biotechnology, 9:74-79, 2014.

10.Churkova, B. and Todorova, P., Chemical composition and nutritional value of bird'sfoot-trefoil in mixtures with perennial grass species. Bulgarian Journal of Crop Science, 45:455-457, 2008.

11.Ilieva, A. and Kyuchukova, A., Content of crude protein and conden ced tannins in varieties of birds food trefoil (Lotus corniculatus L.). Journal of Mountain Agriculture on the Balkans, 12, 1:121-130, 2009.

12.Bozhanska, T., Study on perennial legumegrass mixtures in the conditions of the Central Balkan mountain. Banat's Journal of Biotechnology, 8, 15:34-42, 2017.
BOZHANSKA T., et al

13.Minina, I. P., Meadow grass mixtures. M., Kolos, 1972.

14.Razec, I. and Razec, M., The potential yield of grass-legumes mixtures under different conditions of growth. Grass and Science in Europe, 11:411-413, 2006.

15.Klapp, E., Wiesen und Weiden, Verlag Paul Parey, Berlin-Hamburg, 1971.

16.Pavlov, D., Productivity, nutritional value, qualitative characteristics for the different groups of cforage crops and capacity for predicting them. Dissertation, Stara Zagora, Bulgaria, p.101, 1996.

17.Katova, A., Species and varieties of perennial grasses for high quality forage in Bulgaria. Proceedings of the 14th Meeting of the FAO-CIHEM Mountain Pastures Network, May 30-June 1, 2007, Troyan, Bulgaria, pp: 156-161, 2007.

18. Naydenova, Y. and Katova, A., Forage quality evaluation of perennial grass species in breeding process. Journal of Mountain Agriculture on the Balkans, 13, 6:15191538, 2013,

19.Peeters, A., Wild and sown grasses, Blackwell Publ., FAO Rome, p.311, 2004. 